\title{
Predation by the heterotrophic dinoflagellate Protoperidinium cf. divergens on copepod eggs and early naupliar stages
}

\author{
Hae Jin Jeong
}

Marine Life Research Group, Scripps Institution of Oceanography, University of California San Diego, La Jolla, California 92093-0218, USA

\begin{abstract}
The heterotrophic dinoflagellate Protoperidinium cf. divergens, known as prey for adult copepods, itself feeds on copepod eggs and early naupliar stages. One to several $P$. cf. divergens can attack an egg or nauplius larger than themselves. The time for an egg to be digested was proportional to the number of $P$. cf. divergens attacking it. Ingestion rates of $P$. cf. divergens on Acartia tonsa eggs and on $100 \mu \mathrm{m}$ diameter unidentified eggs with a smooth surface increased linearly with increasing mean prey concentration. Estimated daily consumption of eggs by $P$. cf. divergens suggests that it may sometimes have a considerable predation impact on the populations of copepod eggs. This predation may change the general concept of energy and cycling of carbon in the planktonic community because the genus Protoperidinium and copepods are often amongst the most abundant micro- and macrozooplankton.
\end{abstract}

KEY WORDS: Copepod $\cdot$ Dinoflagellate $\cdot$ Egg $\cdot$ Nauplius Predation

Microzooplanktonic cells ( 20 to $200 \mu \mathrm{m}$ in size) are known to be excellent prey for, and often controlled by, macrozooplankton (>200 $\mu \mathrm{m})$ in aquatic ecosystems (Sherr et al. 1986, Stoecker \& Capuzzo 1990, Ohman \& Runge 1994). However, this study shows that these classic roles could be reversed in 5 to $6 \mathrm{~d}$.

Species in the genus Protoperidinium are ubiquitous heterotrophic dinoflagellates in the world ocean, from the tropics to ice edges (Lessard \& Rivikin 1986, Ochoa \& Gómez 1987, Stoecker et al. 1993). They often dominate the biomass of heterotrophic protists (20 to $200 \mu \mathrm{m}$ in size) and may be important sources of bioluminescence in coastal (Jacobson 1987) and oceanic waters (Lessard 1984, Lapota et al. 1992). They are present all year in the coastal waters off southern California, USA, and possibly most coastal areas (Allen 1949, Hallegraeff \& Reid 1986, Lessard \& Rivikin 1986), and are often particularly abundant during dinoflagel- late red tides (Allen 1949, Jeong unpubl. data) and during diatom blooms (Jacobson 1987).

Laboratory studies have shown that Protoperidinium spp. can prey on diatoms (Hansen 1992, Jacobson \& Anderson 1993), autotrophic dinoflagellates, and cospecies (Hansen 1991, Jeong \& Latz 1994), and have suggested that Protoperidinium spp. could be competitors with macrozooplankton for diatom and dinoflagellate prey.

Protoperidinium spp. feed on prey cells by using a pseudopod 'veil', called the pallium, to envelop the prey, with subsequent external digestion (Gaines \& Taylor 1984, Jacobson \& Anderson 1986). This unique feeding mechanism enables Protoperidinium spp. to feed on prey larger than themselves

For positive population growth, Protoperidinium spp. require fairly high concentrations of suitable phytoplankton prey (approximately $>0.15 \mu \mathrm{g} \mathrm{C} \mathrm{ml}^{-1}$; Jeong \& Latz 1994). However, the abundance of Protoperidinium spp. could be 0.1 to 2.0 Protoperidinium $\mathrm{ml}^{-1}$ in coastal waters even when the concentrations of suitable phytoplankton prey were low (Allen 1949), and Protoperidinium spp. have been found even $200 \mathrm{~m}$ deep where phytoplankton densities are very low (Beers et al. 1975, Nöthig \& Gowing 1991). These observations suggest that Protoperidinium spp. may have important food sources other than phytoplankton.

This study shows that eggs and early naupliar stages of copepods, and possibly other metazoan eggs, could be important prey items for Protoperidinium cf. divergens. This relationship may be very important in the marine food web because Protoperidinium cf. divergens, which is prey for adult copepods (Jeong 1994), is also an important potential predator on copepod eggs and early naupliar stages. This study provides a basis for understanding the interactions and a path of recy- 
Table 1. Design of experiments. Eggs were stored at $0^{\circ} \mathrm{C}$ in the dark. Unidentified egg (egg A): $100 \mu$ m, round, smooth-surface egg

\begin{tabular}{|cccccc|}
\hline Experiment no. & Species & $\begin{array}{c}\text { Prey (egg) } \\
\text { Storage time } \\
\text { (d) }\end{array}$ & $\begin{array}{c}\text { Initial density } \\
\text { (eggs } \mathrm{ml}^{-1} \text { ) }\end{array}$ & $\begin{array}{c}\text { Predator } \\
\text { Protoperidinium } \\
\text { cf. divergens } \\
\text { (ind. } \mathrm{ml}^{-1} \text { ) }\end{array}$ & $\begin{array}{c}\text { Nauplii present } \\
\text { at end of } \\
\text { experiment }\end{array}$ \\
\hline 1 & Acartia tonsa & 1 & $0.032,0.064,0.13,0.26$ & 2 & Yes \\
2 & A. tonsa & 5 & $0.06,0.125,0.25,0.5$ & 2 & No \\
3 & Unidentified egg (Egg A) & 3 & $0.06,0.125,0.25,0.5,0.9$ & 2 & No \\
\hline
\end{tabular}

cling carbon between the populations of Protoperidinium spp. and copepods.

Materials and methods. A population of cultured Protoperidinium cf, divergens (Ehrenberg) Balech (61 $\mathrm{mm}$ in equivalent spherical diameter), originally collected from the Scripps Institution of Oceanography pier during October 1992, was used for these experiments. Details of culturing this species are described by Jeong \& Latz (1994).

Copepods were collected from the coastal waters off La Jolla Bay, California, using a $303 \mu \mathrm{m}$ mesh net. Approximately 80 female Acartia tonsa Dana were distributed amongst three 11 jars, and provided with mixtures of Scrippsiella trochoidea (Stein) Loeblich and Gymnodinium sanguineum Harasaka. Jars were placed in a $15^{\circ} \mathrm{C}$ room, and eggs (about $80 \mu \mathrm{m}$ in diameter, opaque with spines) were collected every day and kept at $0^{\circ} \mathrm{C}$ in the dark. The remaining copepods (several species) were placed in $4 \mathrm{l}$ jars with mixtures of $S$. trochoidea and $G$. sanguineum. Unidentified round eggs (about $100 \mu \mathrm{m}$ in diameter, hereafter Egg A) with a smooth surface and yellowish contents were collected from the jars $3 \mathrm{~d}$ later and also kept at $0^{\circ} \mathrm{C}$ in the dark.

Experiments were designed to measure ingestion rates of Protoperidinium cf. divergens on Acartia tonsa eggs and Egg A (Table 1).

Dense cultures of Protoperidinium cf. divergens were sieved through $54 \mu \mathrm{m}$ mesh; the large cells retained were transferred to a $270 \mathrm{ml}$ polycarbonate (PC) bottle. Most $P$. cf. divergens sieved recovered their normal swimming ability within $30 \mathrm{~min}$. Three $1 \mathrm{ml}$ aliquots from the bottle were counted to determine initial density. In Expt 1, the concentration of $P$. cf. divergens was obtained by volume dilution with an autopipette, and that of Acartia tonsa eggs by individually transferring eggs with a micropipette into duplicate or triplicate $270 \mathrm{mI} \mathrm{PC}$ bottles. In Expts 2 and 3 , the concentrations of both $P$. cf. divergens and eggs were obtained by individual transfer with a micropipette into duplicate or triplicate $32 \mathrm{ml}$ PC bottles. Duplicate control bottles containing only eggs at all prey concentrations were set up. Careful handling of eggs during transfer before and after incubation reduced the loss of eggs to $<10 \%$ in control bottles. The majority of eggs hatched to nauplii during incubation in Expt 1, but did not hatch in Expts 2 and 3.

Experimental and control bottles were placed on rotating wheels at $0.9 \mathrm{rpm}$ under dim light at $19^{\circ} \mathrm{C}$ for 16 to $20 \mathrm{~h}$

Ingestion rates were calculated using Frost's (1972) and Heinbokel's (1978) equations. The final concentrations of Protoperidinium $\mathrm{cf}$, divergens were measured by counting more than 70 cells in Expt 1 and all cells in other experiments in multiwell chambers by removal of individual cells with a micropipette. The final concentrations of eggs and nauplii were measured by counting all eggs and nauplii in multiwell chambers by removal of individual eggs and nauplii.

To record the feeding process of Protoperidinium cf. divergens on copepod eggs and nauplii (which had hatched during the incubation), actively swimming $P$. cf. divergens cells were added by micropipette ( 2 to 4 cells $\mathrm{ml}^{-1}$ ) to three $32 \mathrm{ml} \mathrm{PC}$ bottles containing Acartia tonsa eggs and 2 bottles with Egg A at 0.25 to 2 eggs $\mathrm{ml}^{-1}$. The bottles were placed on rotating wheels under the same conditions as described above. After approximately $17 \mathrm{~h}$ incubation, contents were gently transferred into 2-well chambers, and pictures of $p$. cf. divergens with a pallium, including several stages of the feeding process on eggs or nauplii, were taken continuously for about $7 \mathrm{~h}$ with a Nikon camera and a video camera system on a Zeiss Axiovert 135 inverted microscope at a magnification of 40 or $160 \times$.

To observe feeding in progress, a dense culture of Protoperidinium cf. divergens was placed in multiwell tissue culture plates containing Acartia tonsa eggs. Several $P$. cf. divergens were observed under a dissecting microscope to catch prey immediately. Eggs surrounded by a pallium of 1 ( 5 cases), 2 (5 cases), or 3 ( 3 cases) $P$. cf. divergens cells were individually transferred by a Pasteur micropipette into separate wells of multiwell tissue culture plates containing only freshly filtered seawater. The duration of the feeding process was determined by observing the eggs and cells under a dissecting microscope every 20 to $30 \mathrm{~min}$ for about $8 \mathrm{~h}$. 


\section{A}

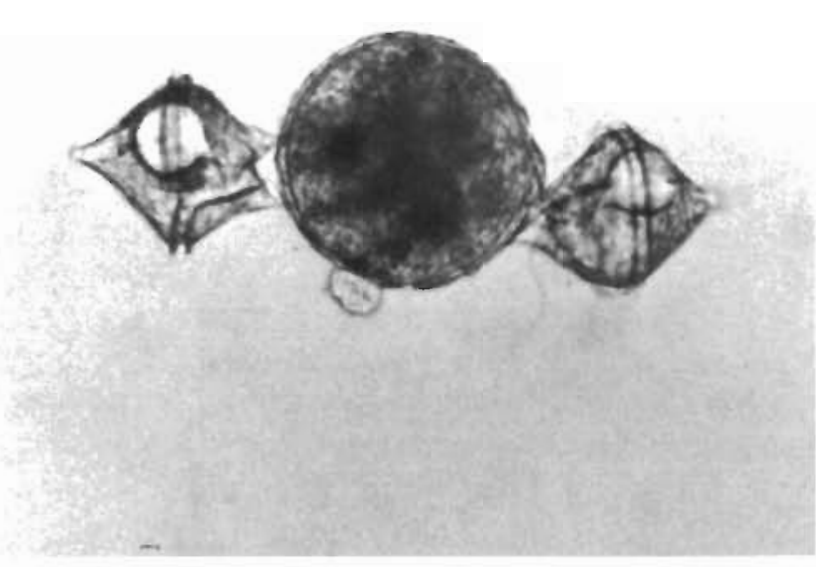

\section{C}

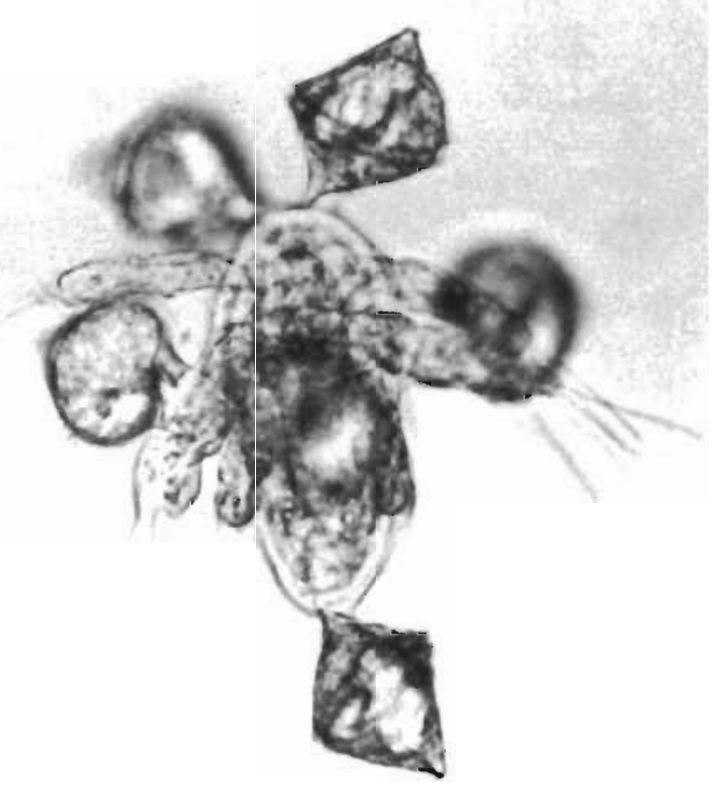

B
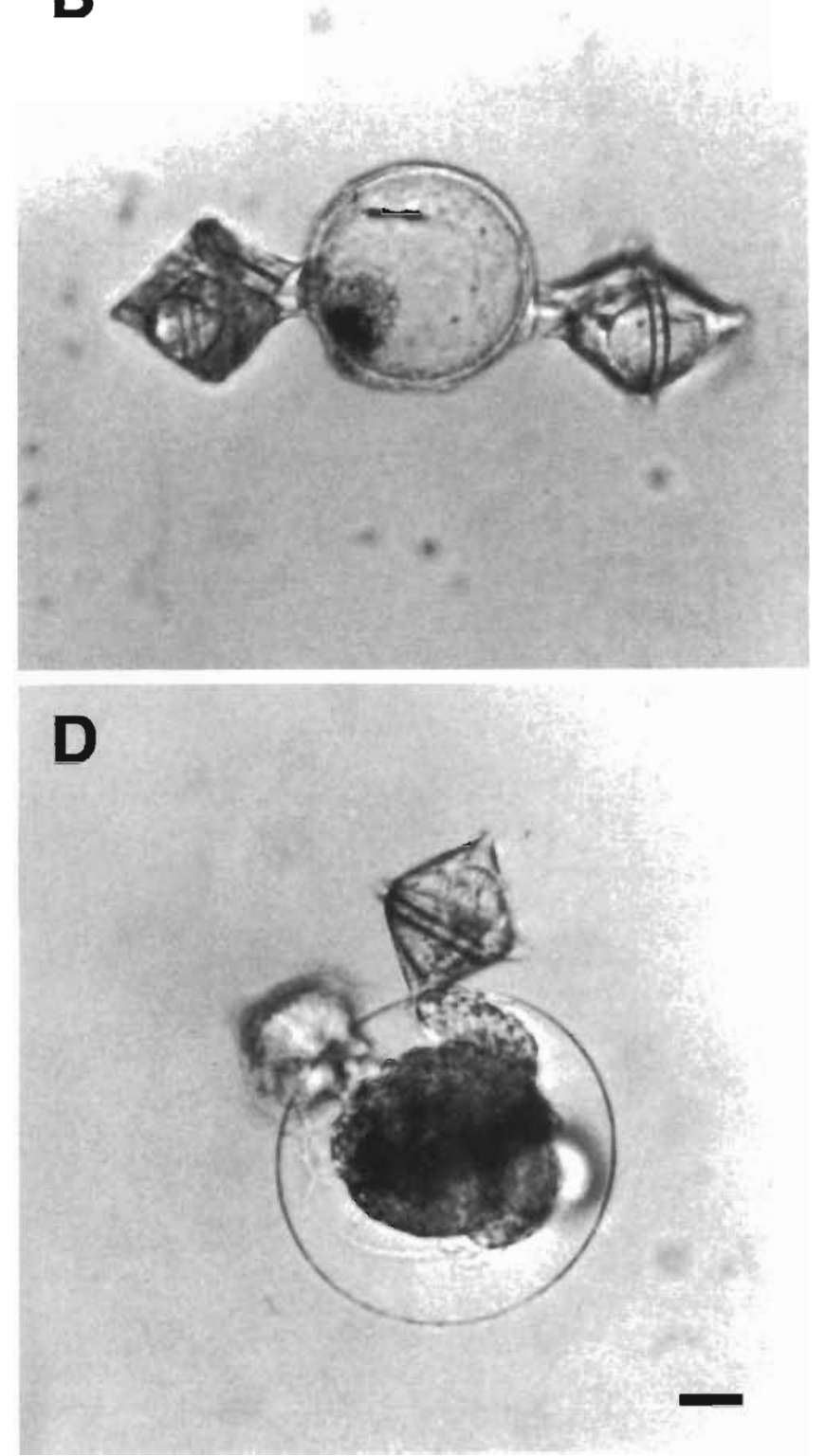

Fig. 1. Protoperidinium cf. divergens feeding on an Acartia tonsa egg and nauplius. (A) Two P. cf. divergens attacking an egg. (B) An egg almost digested. Dark (actually reddish) waste materials accumulated inside the pallium in the vicinity of the first attacking $P$. cf. divergens. (C) Six $P$. cf. divergens attacking a nauplius. (D) A semidigested nauplius. $P$. cf. divergens cells were not the same ones in (A) to (D). Scale bar $=20 \mu \mathrm{m}$

Results. Protoperidinium cf. divergens fed on a copepod egg or early naupliar stages by external digestion after enclosing it in a pallium, as when feeding on autotrophic dinoflagellates (Jeong \& Latz 1994). After one $P$. cf. divergens cell had deployed a pallium around an egg or nauplius, other $P$. cf. divergens cells often also did so quickly (Fig. 1). An egg was attacked by up to $8 P$. cf. divergens simultaneously, and a nauplius by up to 10 . When $P$. cf. divergens had attached a thin filament to a nauplius before pallium deployment, the nauplius darted to escape, but failed to do so. In some cases an egg was completely digested. However, in other cases, when an egg or nauplius had been almost digested, the pallium containing residue or waste materials detached from $P$. cf. divergens cells. $P$. cf. divergens was also observed to deploy a pallium and feed readily on eggs lying on the bottom of a multiwell chamber. One $P$. cf. divergens swam slowly 

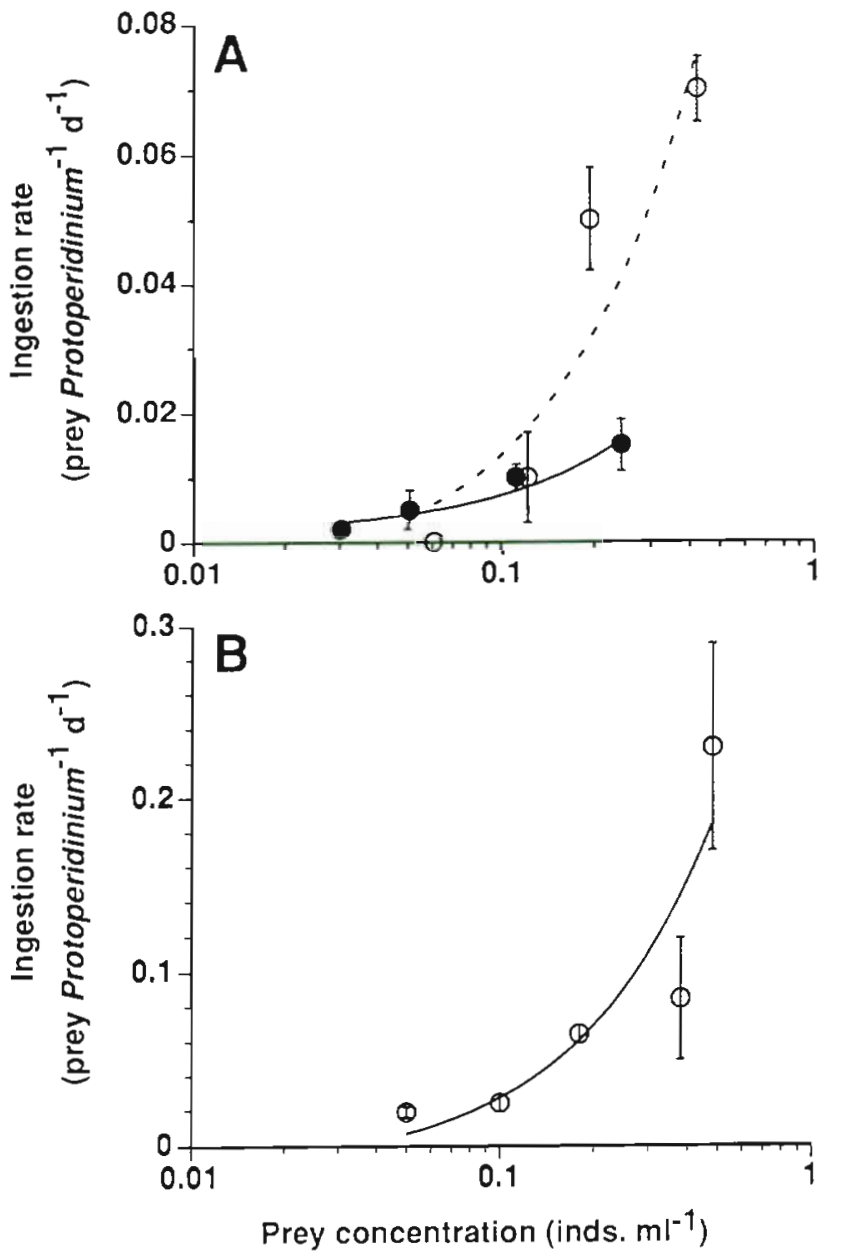

Fig. 2. Ingestion rates (IR) of Protoperidinium cf. divergens. Symbols represent treatment means \pm 1 SE. (A) Acartia tonsa egg or eggs + nauplii diet. (O) Expt 1 (eggs + nauplii); (O) Expt 2 (egg only). (B) Expt 3, Egg A diet. Relations are fitted by linear regression (which appears curved on the semilog plot). (A) Expt 1 (-): IR $=0.0013+0.0598 \mathrm{MPC}\left(\mathrm{R}^{2}=0.741\right)$, where $\mathrm{MPC}$ is mean prey concentration; Expt $2(--)$ : $\mathrm{IR}=$ $-0.0057+0.194 \mathrm{MPC}\left(\mathrm{R}^{2}=0.804\right)$. (B) Expt 3: $\mathrm{IR}=-0.014+$ $0.416 \mathrm{MPC}\left(\mathrm{R}^{2}=0.70\right)$

upward with a egg after enclosing it in its pallium. Other $P$. cf. divergens cells often then attacked the egg. This suggests that Protoperidinium can attack resting eggs on the sediment surface (Kasahara et al. 1975, Landry 1978, Marcus \& Taulbee 1992) as well as pelagic eggs.

The duration of the feeding process depended on the number of Protoperidinium cf. divergens attacking an egg together. Feeding was completed in about 5.2 to $7.3 \mathrm{~h}$ for a single cell's attack, 2.5 to $5 \mathrm{~h}$ for 2 cells, and 1.5 to $2.8 \mathrm{~h}$ for 3 cells.

The ingestion rates of Protoperidinium cf. divergens on total Acartia tonsa prey (eggs + nauplii, Expt 1) and eggs alone (Expt 2) increased continuously with increasing mean prey concentration over the range tested (Fig. 2A). The ingestion rate of $P$. cf. divergens on Egg $\mathrm{A}$ also increased linearly with increasing mean prey concentration over the range tested (Fig. 2B).

Discussion. Reversal of trophic roles of the ubiquitous Protoperidinium and copepods is one of the processes which gives trophic relations in plankton the character of an unstructured web rather than a linear food chain (Isaacs 1976), and contributes to recycling of carbon. For example, Acartia tonsa eggs and nauplii which escape being eaten become copepodite III large enough to feed on P. cf. divergens or smaller Protoperidinium species in 5 to $6 \mathrm{~d}$ (Heinle 1966, Landry 1975 , Miller et al. 1977, Berggreen et al. 1988).

The carbon biomass ratios of an Acartia tonsa egg or nauplius I to a Protoperidinium cf. divergens cell are about 5 (Miller et al. 1977, Kiørboe et al. 1985, Jeong 1994). The ability of Protoperidinium to feed on large, nutritious copepod eggs and nauplii larger than itself, in addition to phytoplankton prey, may be partially responsible for its ubiquity in the world ocean and the maintenance of relatively high abundance even at low phytoplankton prey conditions.

Since the time to digest an egg was proportional to the number of Protoperidinium cf. divergens which deployed a pallium around it, all the $P$. cf. divergens may contribute digestive enzymes. However, waste materials inside a pallium were only observed adjacent to $1 P$. cf. divergens cell, presumably that which had attacked the egg first. Therefore, further study is needed to determine whether secondarily attacking $P$. cf. divergens gains the same amount of organic material from the egg as the first attacking cell.

The ingestion rates of Protoperidinium cf. divergens on copepod eggs increased with increasing mean prey concentration. Data in preliminary study support a continuous linear increase in the ingestion rates at egg concentrations $>1$ egg $\mathrm{ml}^{-1}$. Therefore, the predation impact by $P$. cf. divergens on copepod eggs strongly depends on the densities of both $P$. cf. divergens and copepod eggs.

Although there is much information on egg production rates of copepods (e.g. Checkley et al. 1992), little is known about small-scale egg distributions in the water column (Nielsen et al. 1990). Barnett (1974) reported a maximum density of 1.5 eggs $\mathrm{ml}^{-1}$ for eggs $<100 \mu \mathrm{m}$ in the water column off southern California, although median egg density was only 0.003 eggs $\mathrm{ml}^{-1}$. Krause \& Radach (1980) reported that a peak of copepod egg density sometimes followed that of phytoplankton prey. Therefore, high densities of copepod eggs may follow a peak of suitable diatom or dinoflagellate blooms, when Protoperidinium spp. are also often abundant (Allen 1949, Jacobson 1987, Jeong 
unpubl. data). Several studies (Allen 1949, Paasche \& Kristiansen 1982, Dale \& Dahl 1987, Jacobson 1987) reported abundances $\geq 20$ Protoperidinium $\mathrm{ml}^{-1}$, but during non-phytoplankton-bloom periods the abundance of Protoperidinium could be 0.1 to $2.0 \mathrm{ml}^{-1}$ in coastal waters (Allen 1949)

Based on interpolated ingestion rates (see Fig. 2), I estimate that at a Protoperidinium cf. divergens density of 2 cells ml $\mathrm{ml}^{-1}, 27$ to $33 \%$ of Acartia tonsa eggs and 55 to $69 \%$ of the Egg A population could be consumed in $1 \mathrm{~d}$ at egg concentrations of 0.1 to $0.2 \mathrm{ml}^{-1}$. If copepod eggs form patches, $P$. cf. divergens may aggregate intensively near these and have a higher predation impact on copepod egg populations. However, consumption in the field could be reduced by several factors, such as the predation of copepods on $P$. cf. divergens, and the presence of alternative prey for $P$. cf. divergens. $P$. cf. divergens may also markedly affect copepod egg populations on the sediment surface, where the densities can be high (Kasahara et al. 1974). because it can attack eggs lying on the bottom of the chamber. Some studies (Landry 1978, Ianora \& Buttino 1990) showed the high mortality of copepod eggs in the field. The present study suggests that $P$. cf. divergens predation on copepod eggs may sometimes be responsible.

Protoperidinium with a pallium containing an egg or nauplius of copepods in the field has not yet been reported. Palliums were easily detached when a fixative, Lugol's solution, was introduced. Therefore, conventional sampling and preservation methods might obscure Protoperidinium's feeding on eggs or nauplii in the field.

The large heterotrophic dinoflagellate Noctiluca miliaris has also been observed to feed on Acartia eggs, but it is not fed on by Acartia (Kimor 1979, Daan 1987). In contrast to Protoperidinium, it is present only in coastal waters of temperate regions and only during certain periods. Some ectoparasitic dinoflagellates (Drebes 1984, 1988, Elbrächter 1988) have been reported to attack host eggs and nauplii of some copepods using a peduncle or a peduncle-like organelle.

To understand more fully the interaction between populations of Protoperidinium spp. and copepods, it is worthwhile to explore the small-scale distributions of Protoperidinium and copepod eggs in the water column and on the sediment surface, and to measure the ingestion rates of Protoperidinium on copepod eggs in nature.

Acknowledgements. I thank Michael Mullin, Mark Ohman, David Checkley, Elizabeth Venrick, and Michael Latz for providing facilities and for comments on the manuscript. I also thank Ronald McConnaughey for collecting copepods. This paper was supported by Korean Government Overseas Scholarship and a grant from California Sea Grant Graduate Fel- lowship Program, NOAA. U.S. Department of Commerce (grant number NA89AA-D-SG138, project number E/G-106A).

\section{LITERATURE CITED}

Allen, W. E. (1949). Data files, 1917-1949. Accession No. $81-$ 19. Scripps Institution of Oceanography Archives, University of California, San Diego

Barnett, A. M. (1974). The feeding ecology of an omnivorous neritic copepod, Labidocera trispinosa Esterly. Ph.D. thesis, University of California, San Diego

Beers, J. R., Reid, F. M. H., Stewart, G. L. (1975). Microplankton of the North Pacific central gyre. Population structure and abundance, June, 1973. Int. Rev. ges. Hydrobiol. 60: $607-638$

Berggreen, B., Hansen, B., Kiørboe, T (1988). Food size spectra, ingestion and growth of the copepod Acartia tonsa during development: implications for determination of copepod production. Mar. Biol. 99: 341-352

Checkley, D. M. Jr, Dagg, M. J., Uye, S.-I. (1992). Feeding, excretion and egg production by individuals and populations of the marine, planktonic copepods, Acartia spp. and Centropages furcatus. J. Plankton Res. 14: 71-96

Daan, R. (1987). Impact of egg production by Noctiluca miliaris on the summer development of copepod populations in the southern North Sea. Mar. Ecol. Prog. Ser. 37: 9-17

Dale, T., Dahl, E. (1987). Mass occurrence of planktonic oligotrichous ciliates in a bay in southern Norway. J. Plankton Res. 9: 871-879

Drebes, G. (1984). Life cycle and host specificity of marine parasitic dinophytes. Helgoländer Meeresunters. 37: $603-622$

Drebes, G. (1988). Syltodinium listii gen. et spec, nov., a marine ectoparasitic dinoflagellate on eggs of copepods and rotifers. Helgoländer Meeresunters. 42: 583-591

Elbrächter, M. (1988). Life cycle of Schizochytriodinium calani nov. gen. nov. spec., a dinoflagellate parasiting copepod eggs. Helgoländer Meeresunters. 42: 593-599

Frost, B. W. (1972). Effects of size and concentration of food particles on the feeding behavior of the marine planktonic copepod Calanus pacificus. Limnol. Oceanogr. 17: $805-815$

Gaines, G., Taylor, F. J. R. (1984). Extracellular digestion in marine dinoflagellates. J. Plankton Res. 6: 1057-1061

Hallegraeff, G. M., Reid, D. D. (1986). Phytoplankton species successions and their hydrological environment at a coastal station off Sydney. Aust. J. mar. Freshwat. Res. 37 : $361-377$

Hansen, P. J. (1991). Quantitative importance and trophical role of heterotrophic dinoflagellates in a coastal pelagial food web. Mar. Ecol. Prog. Ser. 73: 253-261

Hansen, P. J. (1992). Prey size selection, feeding rates and growth dynamics of heterotrophic dinoflagellates with special emphasis on Gyrodinium spirale. Mar Biol. 114: $327-334$

Heinbokel, J. F. (1978). Studies on the functional role of tintinnids in the Southern California Bight. I. Grazing and growth rates in laboratory cultures. Mar. Biol. 47: 177-189

Heinle, D. R. (1966). Production of a calanoid copepod, Acartia tonsa, in the Patuxent River estuary. Chesapeake Sci. 7 : $59-74$

Ianora, A., Buttino, I. (1990). Seasonal cycles in population abundances and egg production rates in the planktonic copepods Centropages typicus and Acartia clausi. J. Plankton Res. 12: 473-481 
Isaacs, J. D. (1976). Reproductive products in marine food webs. Bull. South. Calif. Acad. Sci. 75: 220-223

Jacobson, D. M. (1987). The ecology and feeding biology of thecate heterotrophic dinoflagellates. Ph.D. thesis, Woods Hole Oceanographic Institution/Massachusetts Institute of Technology Joint Program

Jacobson, D. M., Anderson, D. M. (1986). Thecate heterotrophic dinoflagellates: feeding behavior and mechanisms. J. Phycol. 22: 249-258

Jacobson, D. M., Anderson, D. M. (1993). Growth and grazing rates of Protoperidinium hirobis Abé, a thecate heterotrophic dinoflagellate. J. Plankton Res. 15: 723-736

Jeong, H. J. (1994). Predation effects of the calanoid copepod Acartia tonsa on a population of the heterotrophic dinoflagellate Protoperidinium cf divergens in the presence of co-occurring red-tide dinoflagellate prey. Mar. Ecol. Prog. Ser. 111:87-97

Jeong, H. J., Latz, M. I. (1994). Growth and grazing rates of the heterotrophic dinoflagellate Protoperidinium spp. on red tide dinoflagellates. Mar. Ecol. Prog. Ser. 106: 173-185

Kasahara, S., Uye, S., Onbé, T. (1974). Calanoid copepod eggs in sea-bottom muds. Mar. Biol. 26: 167-171

Kasahara, S., Uye, S., Onbé, T. (1975). Calanoid copepod eggs in sea-bottom muds. II. Seasonal cycles of abundance in the populations of several species of copepods and their eggs in the inland sea of Japan. Mar. Biol. 31: 25-29

Kimor, B. (1979). Predation by Noctiluca miliaris Souriray on Acartia tonsa Dana eggs in the inshore waters of southern California. Limnol. Oceanogr. 24: 568-572

Kiørboe, T., Møhlenberg, F., Hamburger, K. (1985). Bioenergetics of the planktonic copepod Acartia tonsa: relation between feeding, egg production and respiration, and composition of specific dynamic action. Mar. Ecol. Prog. Ser. 26: 85-97

Krause, M., Radach, G. (1980). On the succession of developmental stages of herbivorous zooplankton in the northern North Sea during FLEX '76. I. First statements about the main groups of the zooplankton community. 'Meteor' Forsch.-Ergebn. 22: 133-149

Landry, M. R. (1975). The relationship between temperature and the development of life stages of the marine copepod Acartia clausi Giesbr. Limnol. Oceanogr. 20:854-857

Landry, M. R. (1978). Population dynamics and production of a planktonic marine copepod, Acartia clausii, in a small

This note was presented by D. K. Stoecker (Senior Editorial Advisor), Cambridge, Maryland, USA temperate lagoon on San Juan Island. Washington. Int. Rev. ges. Hydrobiol. 63: 77-119

Lapota, D., Rosenberger, D. E., Liederman, S. H. (1992). Planktonic bioluminescence in the pack ice and the marginal ice zone of the Beaufort Sea. Mar. Biol. 112:665-675

Lessard, E. J. (1984). Oceanic heterotrophic dinoflagellates: distribution, abundance and role as microzooplankton. Ph.D. thesis, University of Rhode lsland, Kingston

Lessard, E. J., Rivikin, R. B.(1986). Nutrition of microzooplankton and macrozooplankton from McMurdo Sound. Antarct. J. U.S. 21: $187-188$

Marcus, N. H., Taulbee, K. (1992). Potential effects of a resuspension event on the vertical distribution of copepod eggs in the sea bed: a laboratory simulation. Mar. Biol. 114: $249-251$

Miller, C. B., Johnson, J. K., Heinle, D. R. (1977). Growth rules in the marine copepod genus Acartia. Limnol. Oceanogr 22: $326-334$

Nielsen, T. G., Kiørboe, T., Bjørnsen, P. K. (1990). Effects of a Chrysochromulina polylepis subsurface bloom on the planktonic community. Mar. Ecol. Prog. Ser. 62: 21-35

Nöthig, E. M., Gowing, M. M. (1991). Late winter abundance and distribution of phaeodarian radiolarians, other large protozooplankton and copepod nauplii in the Weddell Sea, Antarctica. Mar. Biol. 111: 473-484

Ochoa, N., Gómez, O. (1987). Dinoflagellates as indicators of water masses during El Niño, 1982-1983. J. geophys. Res. 92: $14355-14367$

Ohman, M. D., Runge, J. A. (1994). Sustained fecundity when phytoplankton resources are in short supply: omnivory by Calanus finmarchicus in the Gulf of St. Lawrence. Limnol. Oceanogr. 39: 21-36

Paasche, E., Kristiansen, S. (1982). Ammonium regeneration by microzooplankton in the Oslofjord. Mar. Biol. 69: 55-63

Sherr, E. B., Sherr, B. F., Paffenhöfer, G. A. (1986). Phagotrophic protozoa as food for metazoans: a 'missing link in marine pelagic food webs. Mar. microb. Food Webs 1. $61-80$

Stoecker, D. K., Buck, K. R., Putt, M. (1993). Changes in the sea-ice brine community during the spring-summer transition, McMurdo Sound, Antarctica. II. Phagotrophic protists. Mar. Ecol. Prog. Ser. 95: 103-113

Stoecker, D. K., Capuzzo, J. M. (1990). Predation on protozoa: its importance to zooplankton. J. Plankton Res. 12 891-908

Manuscript first received: May 5, 1994

Revised version accepted: July 1, 1994 